Maurer School of Law: Indiana University

Digital Repository @ Maurer Law

\title{
Lawyers Seeking Clients, Clients Seeking Lawyers: Sources of Contingency Fee Cases and Their Implications for Case Handling
}

Jayanth K. Krishnan

Indiana University Maurer School of Law, jkrishna@indiana.edu

Herbert M. Kritzer

University of Minnesota Law School

Follow this and additional works at: https://www.repository.law.indiana.edu/facpub

Part of the Legal Profession Commons

\section{Recommended Citation}

Krishnan, Jayanth K. and Kritzer, Herbert M., "Lawyers Seeking Clients, Clients Seeking Lawyers: Sources of Contingency Fee Cases and Their Implications for Case Handling" (1999). Articles by Maurer Faculty. 538.

https://www.repository.law.indiana.edu/facpub/538

This Article is brought to you for free and open access by the Faculty Scholarship at Digital Repository @ Maurer Law. It has been accepted for inclusion in Articles by Maurer Faculty by an authorized administrator of Digital Repository@ Maurer Law. For more information, please contactrvaughan@indiana.edu. 


\title{
Lawyers Seeking Clients, Clients Seeking Lawyers: Sources of Contingency Fee Cases And Their Implications for Case Handling*
}

\author{
HERBERT M. KRITZER \\ and \\ JAYANTH K. KRISHNAN
}

\begin{abstract}
Where do the clients of contingency fee lawyers come from, and what are the implications of client sources for contingency fee practice? Those are the questions this paper considers, drawing upon multiple sources of data. The analysis shows that relatively few clients come to lawyers' offices in response to advertising. Rather, it is the more traditional route of reputationally based referrals that bring in the vast majority of contingency fee clients. The importance of maintaining a reputation that will draw in future clients tends to curb the potential for abuses created by the inherent conflict of interest between lawyer and client that the contingency fee creates.
\end{abstract}

\section{INTRODUCTION}

From the early years of the twentieth century, the contingency fee lawyer acquired the image of the "ambulance chaser" (see Bergstrom 1992:92-93; Karsten 1998). This image, whether accurate or not, flows in part from the structure of the typical American contingency fee: Lawyers are paid on a percentage of recovery or commission basis which creates incentives for lawyers to seek out potentially "profitable" cases. States generally prohibit lawyers from initiating contact with potential personal injury clients in person or by telephone, although news reports of major disasters often portray hordes of hungry lawyers or their agents converging on the scene just behind accident investigators (see, e.g., Lyons \& Blum 1996; Biederman 1996; Davis 1995; MacLachlan 1993; Stanley 1991; Blum 1987; Taylor

\footnotetext{
* The research reported in this article was supported by the National Science Foundation's Law and Social Science Program, Grant No. SBR-9510976. The authors would like to thank Jerry Van Hoy, Stephen Daniels, Joanne Martin, and the anonymous referees for very helpful comments.

Both authors may be contacted at the Department of Political Science, University of Wisconsin, 1050 Bascom Mall, Madison, WI 53706. The senior author may be contacted via e-mail atkritzer@polisci.wisc.edu.
} 
1986). Furthermore, the dictates of the lawyers' own notions of professionalism sharply constrain the types of activities many, if not most, lawyers employ in attracting clients with potentially lucrative cases to their offices.

Nonetheless, the expectations of economic rationality appear to coincide with criticisms of contingency fee legal practice (Brickman 1989; Horowitz 1995). As profit maximizers, lawyers should be encouraged by a percentagebased fee to look at each case in terms of its profit potential, and this leads to incentives for lawyers to:

- seek out cases with high fee potential;

- avoid cases where the risk of losing is high; and

- choose to dispose of cases so as to maximize the lawyer's own benefit rather than the client's benefit.

The critics contend that the result of these incentives is that contingency fee lawyers primarily serve their own economic self-interest in a way that conflicts with the ends of justice for their clients and/or society as a whole. ${ }^{1}$ These critics place little faith in the power of professionalism as a means of stopping lawyers from looking out only for their own interests. What critics fail to point out, or perhaps fail to realize, is that there are important economic constraints on lawyers, which have the effect of preventing them from neglecting the interests of their clients. Those constraints flow from the need of lawyers to think in terms of their long-run interest rather than just the immediate case, and this long-run interest is determined primarily by their ability to secure future contingency fee clients.

As with all professional service providers, securing clients is a key concern for lawyers. In fact, the rapid growth, although not the origin, of the contingency fee probably reflected the need of more marginal practitioners to secure clients because the potential clients who had an ability to pay for legal services normally shunned those practitioners (Powell 1988:24; Auerbach 1976:40-53; Carlin 1962:22-23, 129-36). A key element in client acquisition by contingency fee lawyers, something that sets them apart from other service providers, is that a lawyer representing a client on a contingency basis provides services beyond those that are solely legal. Often it is the additional services - for example, banking services (advancing costs) and insurance services (absorbing losses when they occur $^{2}$ ) - that make it possible for the client to hire the lawyer. The inclusion of these additional services means that a contingency fee lawyer's cases constitute something best thought of as a portfolio of investments involving significant risk. Part of the risk arises from uncertainty over whether or not any fee will be obtained (what most people think of as the "contingency" in the contingent fee). Much more risk concerns the issue of whether or not the fee will be "adequate." This latter risk arises from uncertainty over the amount that will be recovered and the size of the lawyer's investment that will be necessary to secure that recovery. These various risks lead lawyers to take care in making decisions to add cases to their "portfolios." ${ }^{33}$ However, before 
a lawyer can begin to consider whether or not to take particular cases, the lawyer has to find clients with those cases.

Where, then, do most lawyers obtain their contingency fee cases, and what differences do the sources of cases make? This is an important question, both from a policy perspective and from the perspectives of theories of civil justice. What we show in this article is that the single most important element in a lawyer's ability to attract contingency fee clients is the lawyer's reputation. The need to establish and maintain a reputation serves to check the potential conflicts of interest between lawyers and their contingency fee clients (see Rosenthal 1974; Johnson 1980-81; Miller 1987; Kritzer 1991:100-5).

To provide evidence on where lawyers get their clients, we rely upon a study of contingency fee legal practice in Wisconsin. The pattern we will describe closely tracks the patterns described by Daniels and Martin for Texas $(1997,1999)$ and by Van Hoy for Indiana (1997a). The Texas and Indiana studies rely on detailed, in-depth interviews with practitioners; in the Wisconsin study we use a combination of sources (including a small number of practitioner interviews), and find the same general pattern of client sources. Our sources of data include:

- the mail survey responses of $511 \mathrm{Wisconsin}$ lawyers ${ }^{4}$ who regularly do work on a contingency basis; ${ }^{5}$

- three months of observation in lawyers' offices involving three different law firms;

- semi-structured interviews with twenty-eight practitioners who do contingency fee work;

- a telephone survey of Wisconsin recipients of direct mail solicitations; and

- a telephone survey that included questions to Wisconsin residents on whether or not they had existing predilections concerning which lawyer or law firm they would use for an injury case.

In the Appendix we describe each of these data sources in more detail. In the following sections we will first draw on the survey of Wisconsin lawyers to look at the general pattern of sources of clients. We will then look at six different case sources and discuss their roles in structuring the lawyers' portfolios of cases.

\section{WHERE DO CLIENTS COME FROM?}

\section{A. AN OVERVIEW}

As part of the survey of Wisconsin lawyers, we asked the respondents to tell us what percentage of their contingency fee cases came from each of the following: 
- referrals from other lawyers;

- referrals from other clients;

- the Yellow Pages;

- other advertising (TV, etc.);

- existing clients;

- community contacts, or word of mouth;

- direct mail advertising;

- other; and

- unknown.

A total of 471 lawyers provided usable responses to this question. To summarize this information, we computed the mean percentage for each source. Table 1 shows these means: for all of the lawyers in the sample, for those who identify themselves as personal injury plaintiffs' specialists, and for those who do not identify as personal injury plaintiffs' specialists.

Given the public debate about lawyer advertising and direct-mail solicitation of potential clients, one might think that these initiatives constitute major sources of clients for most lawyers. In fact, the clearest pattern in the table is the relative unimportance of these two controversial sources: Direct mail accounts for an average of less than 1 percent, and advertising other than in the Yellow Pages for only about 3 percent for all lawyers and 8 percent for personal injury specialists (contrast to Van Hoy's (1997:12-14) findings regarding franchise law firms); of the modern advertising-based sources of clients, only the Yellow Pages account for as much as 10 percent (16 percent for personal injury specialists). The dominant source of clients is the combination of what we label "traditional" sources because they reflect the means that private practice lawyers have employed to secure clients; these include client referrals, lawyer referrals, existing clients, and community contacts. One of the more intriguing elements here is the significance of "existing clients." For those lawyers who are not personal injury (PI) specialists, one might expect that a sizable proportion of their contingency fee clients would have previously retained the lawyer for some other type of matter. However, even for the personal injury specialists, more clients on average come as "existing clients" (who usually are repeat, rather than existing, clients) than come from the combination of media advertising and direct mail.

The pattern shown in Table 1 obscures the lawyer-to-lawyer variation in client sources. One way to try to see the variation is to look at each lawyer's largest source of contingency fee clients. First, to what degree do individual lawyers tend to have a clearly dominant source of clients? Table 2 shows the percentage of clients coming from whichever source produces the lawyer's largest proportion of clients; the table shows this separately for all respondents, for those respondents who are personal injury plaintiffs' specialists, and for those who are not. Because this table is displaying percentages about percentages, it might be useful to use an example to make 
clear what it is saying: among PI specialists, 27 percent of the lawyers get between 20 and 35 percent of their clients from the largest single source while 31 percent get between 50 and 65 percent from their largest source.

Table 2 contains several interesting patterns. First, the mean percent from the largest source is fifty-one, and 58 percent of the respondents obtained half or more of their cases from just one of the sources shown in Table 1. However, those who were not PI specialists were more likely to have a dominant source of cases - that is, half or more of their cases coming from a single source - than were PI specialists (62 percent versus 47 percent).

Table 3 shows information on the nature of the client sources that the lawyers identified as producing the most clients. The pattern in this table confirms the dominance of traditional sources of clients. Overall, only 21 percent of the respondents report that the largest source of clients included Yellow Pages advertising, direct mail, or other advertising; ${ }^{6}$ among those for whom a source provided at least half of their contingency fee clients, less than 10 percent relied upon one of these sources. Even among personal injury specialists, less than 17 percent reported that half or more of their clients came from one of the advertising-based sources. If we combine Yellow Pages, direct mail, and other advertising into a single "advertising" category, this still does not constitute a dominant source for many lawyers: 15 percent of PI specialists obtain half or more of their contingency fee clients through advertising as did 13 percent of other lawyers.

The dominance of traditional client sources is also evident from the semi-structured interviews. One set of the questions asked during the interviews concerned the contingency fee case that the lawyer had most recently closed. In most interviews (twenty of twenty-seven) the lawyer reported the source of the case: eight referrals from a prior client, three referrals from friends, three referrals from lawyers outside the firm, two referrals from medical providers, two "cold calls" (source not otherwise

Table 1: Sources of Cases

\begin{tabular}{lccc}
\hline Source & $\begin{array}{c}\text { All } \\
\text { Respondents }\end{array}$ & $\begin{array}{c}\text { PI } \\
\text { Specialists }\end{array}$ & $\begin{array}{c}\text { Not PI } \\
\text { Specialists }\end{array}$ \\
\hline Lawyer referrals & $19.4 \%^{\mathrm{a}}$ & $19.1 \%$ & $19.6 \%$ \\
Client referrals & 25.3 & 27.7 & 25.2 \\
Existing client & 19.2 & 11.4 & 23.0 \\
Yellow Pages ad & 10.6 & 16.0 & 7.9 \\
Other advertising & 3.0 & 7.7 & 0.6 \\
Direct mail & 0.2 & 0.5 & $<0.1$ \\
Community contacts & 15.4 & 13.6 & 16.3 \\
Other and unknown & 6.9 & 5.9 & 7.4 \\
\multicolumn{1}{c}{ (n) } & $(471)$ & $(153)$ & $(318)$ \\
\hline
\end{tabular}

${ }^{a}$ Cell entries are the mean percentage reported for the source. 
Table 2: Dominance of Case Sources

\begin{tabular}{lccc}
\hline $\begin{array}{l}\text { Percent of Cases from } \\
\text { Lawyer's Largest Source }\end{array}$ & $\begin{array}{c}\text { All } \\
\text { Respondents }\end{array}$ & $\begin{array}{c}\text { PI } \\
\text { Specialists }\end{array}$ & $\begin{array}{c}\text { Not PI } \\
\text { Specialists }\end{array}$ \\
\hline $20-35 \%$ & $23 \%$ & $27 \%$ & $22 \%$ \\
$36-49 \%$ & 19 & 26 & 16 \\
$50-65 \%$ & 37 & 31 & 40 \\
$66-100 \%$ & 21 & 16 & 22 \\
(n) & $(471)$ & $(153)$ & $(318)$ \\
mean percent & 51 & 48 & 52 \\
median percent & 50 & 44 & 50 \\
\hline
\end{tabular}

$\chi^{2}=10.78$, d.f. $=3, p=.013$

Table 3: Largest Sources of Cases

\begin{tabular}{lccccccc}
\hline Largest Source & \multicolumn{3}{c}{ All Respondents } & & \multicolumn{2}{c}{ Has a } & Dominant Source \\
\cline { 2 - 4 } \cline { 7 - 8 } & All & PI & Not PI & & All & PI & Not PI \\
& & Spec. & Spec. & & Spec. & Spec. \\
\hline Other lawyers & $25 \%^{\mathrm{b}}$ & $24 \%$ & $26 \%$ & & $24 \%$ & $22 \%$ & $24 \%$ \\
Yellow Pages & 16 & 26 & 11 & & 8 & 12 & 7 \\
Existing or prior client & 24 & 9 & 31 & & 25 & 8 & 31 \\
Direct mail & $<1$ & 1 & & & $<1$ & 1 & - \\
Referred by prior client & 38 & 38 & 39 & & 34 & 39 & 32 \\
Other advertising & 5 & 14 & 1 & 1 & 3 & - \\
Community contact & 19 & 12 & 22 & & 13 & 8 & 14 \\
(number of & $(471)$ & $(153)$ & $(318)$ & & $(270)$ & $(72)$ & $(198)$ \\
respondents) & & & & & & \\
\hline
\end{tabular}

${ }^{a}$ Includes only lawyers reporting $50 \%$ or more of cases from a single source.

${ }^{b}$ Percentages may sum to more than 100 due to equal percentages from multiple sources.

reported), one referral from another lawyer in the firm, and one referral through the Yellow Pages.

As we will discuss in some detail in the sections that follow, the observational data are also consistent with this pattern. All three of the lawyers in whose practices the senior author observed full time over a onemonth period rely mostly on referrals from satisfied clients and other contacts in the community; this was true even for one lawyer who was a heavy user of the media and the Yellow Pages.

The patterns we found are not surprising. Other recent analyses of personal plight legal practice (Daniels \& Martin 1999; Van Hoy 1997a; Seron 1996:48-66) generally reported that relatively few lawyers rely upon 
advertising techniques, although it is not unusual for a lawyer to experiment with advertising or to use advertising as a secondary source; we could find only one study that reported heavy reliance on advertising, and that dealt specifically with franchise, store-front law firms (Van Hoy 1995: 716). In fact, the patterns found by us and others from recent research efforts do not differ substantially from patterns reported thirty to forty years ago (see, e.g., Reed 1969: 71).

We now turn to look in more detail at each of the types of client sources.

\section{B. DIRECT MAIL}

Direct mail solicitation of clients is controversial. A number of states have tried to ban such contacts, but in 1988 the U.S. Supreme Court in Shapero $v$ Kentucky Bar Association (1988) ruled that states could not do so. In a later case, Florida Bar $v$ Went-For-It, Inc. (1995), the Court ruled that states could bar lawyers from sending such solicitations for thirty days. Even so, some professional organizations of plaintiffs' lawyers actually include as a condition of membership an agreement not to engage in direct mail solicitation (Daniels \& Martin 1999:389-90).

In Wisconsin, lawyers are permitted to send letters to persons injured in accidents. In these letters, lawyers can provide information about themselves and the tort compensation system, and they can offer their services to the recipients. The rules established by Wisconsin Board of Attorneys Professional Responsibility (BAPR) require lawyers contacting potential personal injury clients by mail to file copies of their mailings and lists of recipients with BAPR. The number of law firms actively using direct mail at any one time is relatively small, so it is not necessarily surprising that the average proportion of clients coming from direct mail is low. Only eight of the 471 respondents in the practitioner survey reported that they were currently using direct mail. ${ }^{7}$ Moreover, even among those using direct mail, most report that direct mail accounts for a very small proportion of their cases; one lawyer reported the figure to be 50 percent, two reported 15 percent, four reported 5 percent, and one reported only 1 percent. Several lawyers participating in the semi-structured interviews were aggressive users of direct mail, but they reported that only a small proportion of their clients (under 20 percent) actually came from that source.

In 1996, BAPR commissioned a survey of recipients of direct mail as part of its consideration of whether or not to impose a thirty-day rule (i.e., to ban such mailings for thirty days following the injury). The survey produced data from 503 respondents. Among those who recalled receiving one or more letters from lawyers, only about 5 percent actually contacted one of those firms (computed from Sweet 1997:11-12). Of those persons who eventually hired a lawyer, 11 percent reported that they had hired someone from a firm that had sent the injured person a solicitation after the accident. Given that fewer than 50 percent of the respondents reported hiring a lawyer 
(ibid.:17), and that the average respondent who recalled receiving at least one letter reported receiving about five letters (ibid.:13), we estimate that the yield rate from the letters was only about 2 percent. Interestingly, even though only 5 percent of those receiving letters eventually hired an attorney who had sent a letter, 10 percent of the respondents who read the letter reported that it had been in some way helpful. Nonetheless, whether we look at it from the perspective of all attorneys doing contingency fee work, attorneys who use direct mail as a source of contingency fee clients, or persons injured in accidents who receive direct mail solicitation, direct mail appears to play a relatively small role in connecting lawyers with potential clients.

\section{MEDIA ADVERTISING}

Bates v State Bar of Arizona (1977) eliminated state bans on advertising by lawyers. Since 1977 , lawyers have tried a variety of ways to use television and radio to draw clients to their doors (Bowen 1995a). Most lawyers who have tried media advertising have abandoned it as too expensive and relatively ineffective, at least at the level of advertising that they could afford. ${ }^{8}$ Our survey shows that advertising plays a measurable role in attracting clients for those lawyers who use it. Across our sample of lawyers an average of 3 percent of clients come from advertising other than the Yellow Pages; ${ }^{9}$ this figure rises to about 8 percent for personal injury specialists. Among the respondents to the BAPR survey of direct mail recipients, only 3.5 percent of those hiring lawyers reported that they chose their lawyers on the basis of television advertising (Sweet 1997: 18) ${ }^{10} \mathrm{~A}$ minority ( 37 percent) of personal injury specialists use non-Yellow Pages advertising; among those who do, most obtained fewer than a third of their clients through it (and almost none obtained half or more of their clients this way).

One of the reasons that more lawyers do not rely on aggressive television (or radio) advertising is that it can generate very large numbers of telephone calls from persons with weak or nonexistent cases (or cases entirely outside the area of the lawyers' or firms' expertise). The result is that firms must set up systems to handle the influx of calls, systems that can add substantially to office overhead (compare to Van Hoy 1997a: 19; Daniels \& Martin 1999: 390). Lawyers in one firm, which was a heavy user of television advertising, reported that when the ads were running they could expect ten or more calls a day. Most of the calls concerned cases that had no significant fee potential, or types of cases that the firm did not handle (or that could not be handled on a contingency basis); ${ }^{11}$ the lawyers in this firm were happy if a week's worth of phone calls yielded two or three cases. One lawyer in this firm estimated that advertising (via both media and the Yellow Pages) directly produced only about one quarter of his revenue, although he attributed another quarter to indirect effects of advertising 
(i.e., referrals from former clients who themselves originally went in as a result of the advertising).

A number of the lawyers interviewed reported that they use radio as an advertising medium. There are obvious reasons for this: It is much less costly than television, and it is easier to reach a specific target audience, both geographically 12 and need-based ("drive time" is an effective time to reach people with potential worker's compensation claims or auto-accident-injury claims). Radio, furthermore, might not carry the stigma that television advertising does. However, at least some lawyers see radio as having the same disadvantages as television; one lawyer who had run radio spot advertisements for a period of time reported that "they gained us some notoriety but not a lot of clients."

One of the problems for potential advertisers in Wisconsin is the dominant media position that has been established by one statewide firm, Habush, Habush, Davis \& Rottier. ${ }^{13}$ The Habush firm is an aggressive user of advertising including television, radio, ${ }^{14}$ the Yellow Pages (the firm has the back cover on many telephone books around the state), and billboards. While the Habush firm has the reputation of being very selective in accepting cases, it nonetheless generates a very large volume of telephone calls, and has an elaborate system for screening those calls. In the statewide Wisconsin Opinions survey (see Appendix for details), we asked the following questions:

If you were injured in an accident and decided to contact a lawyer to possibly represent you, can you think of the names of any lawyers or law firms that you would likely call?

What are the names of those lawyers or law firms?

About 50 percent of the respondents said, "yes" to the first question, and of those who then specifically named a lawyer or firm, 15 percent named Habush; the next highest figure was 4 percent (for a Milwaukee-based firm). Since the question required respondents to recall the names of law firms, the 15 percent who could recall Habush are undoubtedly less than the percentage who would have recognized the Habush firm's name if it had been on a list that was read to the respondents. Habush has effectively established a brand name and aggressively defends the name by increasing media advertising in response to ad campaigns by firms it views as potential competitors. Importantly, Habush's successful use of advertising is closely tied to its success in handling large, complex cases; its advertising is successful because the firm has a reputation for delivering a high-quality "product."

Taken together, these details suggest the difficulty that most lawyers face in considering the "television alternative." First, a firm must be prepared to handle an influx of calls, most of which will not be from clients the firm wants. Second, the firm must be prepared to use advertising over the long haul. ${ }^{15}$ Third, a firm probably must tie media visibility to visibility in other 
arenas (e.g., the Yellow Pages). Fourth, the firm must deliver results, or the flow of clients will disappear as word spreads regarding the firm's lack of success. Finally, the cases that come in from aggressive advertising may not be particularly strong; several lawyers who are aggressive advertisers commented during interviews that their best cases come not from the advertising but from word-of-mouth referrals or repeat clients. ${ }^{16}$

\section{THE YELLOW PAGES}

Open any telephone book with a Yellow Pages section, and the largest group of advertisers almost certainly will be attorneys. It is not altogether clear how much attorneys have in fact benefitted from Yellow Pages advertising (although we have no doubt that those who market the Yellow Pages would fight to the bitter end should a constitutional amendment that would ban such advertising be introduced). As a form of explicit advertising, the Yellow Pages are clearly the most important medium (see also Daniels \& Martin 1999:389), with lawyers estimating that an average of 10 percent of clients (16 percent for personal injury specialists) come from this source. Interestingly, lawyers may overestimate the role of Yellow Pages advertising as a source of clients; in the BAPR survey of direct mail recipients, only 3.5 percent of the respondents named the Yellow Pages as the way they chose the lawyers they hired (Sweet 1997:18); only one of the twenty cases described by lawyers during the semi-structured interviews involved clients known to have found the lawyer through the Yellow Pages. ${ }^{17}$

This suggests that potential clients may not be as naive as some lawyers would like to believe. Any lawyer with enough money may purchase a fullpage Yellow Pages advertisement stating his or her availability to handle personal injury or other contingency fee cases; it might be a lawyer with a long record of success with such cases (such as the Habush firm) or it might be J. Q. Lawyer, who just graduated from law school (near the bottom of his or her class) but who happens to have access to the finances needed for such advertising. On more than one occasion, we have heard lawyers talk disparagingly about some of their competitors who are prominent users of the Yellow Pages (i.e., "This guy couldn't try a simple rear-end collision case"). It appears that the potential clients do not find the large Yellow Pages ads to be all that helpful; persons seeking lawyers do not rely upon the Yellow Pages as much as the lawyers spending large amounts of money on such ads appear to believe.

One final caveat about the Yellow Pages: It may be that they are a very useful device for assisting potential clients with name recognition. For example, recall that only about 7 or 8 percent of the respondents in the statewide Wisconsin Opinions survey spontaneously named the Habush firm as the one they would call if they were seeking representation after a significant injury. Habush has very prominent advertisements in the Yellow Pages (as do other firms with established reputations and/or those that use a 
lot of television advertising). These ads may serve to help potential clients recall the name of a firm when those clients find themselves in possible need of a lawyer. We have no way of assessing this secondary, albeit potentially important, role of Yellow Pages advertising.

\section{E. REFERRALS FROM OTHER LAWYERS}

The lawyers in the Wisconsin survey estimate that just under 20 percent of their clients come as referrals from other lawyers; ${ }^{18}$ this figure does not vary depending on whether or not the lawyer is a personal injury plaintiffs' specialist. ${ }^{19}$ Referrals from other lawyers can come either on a fee-sharing basis or on a non-sharing basis. In some situations, paid referrals are an extremely important part of a lawyer's business (see Daniels \& Martin 1999:386-87), and the "referral fee" may range as high as 50 percent of the overall fee that is eventually collected. Unfortunately, our survey did not specifically distinguish between paid and unpaid referrals, in part because of an initial assumption, based on existing literature (e.g., Carlin 1962:82, 162) that most lawyer-to-lawyer referrals involved some fee splitting. ${ }^{20}$ The observational phase of the research revealed that most referrals do not involve payments, but rather simply reflect the lawyer's desire to direct potential clients to another lawyer who might be able to handle the matter in question. In two of the three observed offices, there was at least some work handled on a referral fee basis (in one office this included cases referred in as well as cases referred out). However, many more cases were referred elsewhere because the lawyers did not handle particular types of work; typically these referrals involved the lawyer (or the lawyer's receptionist) giving the caller the name(s) of one or more other firms to contact. For example, in one observed office, the lawyer (Adams) did not handle any worker's compensation; when a former client called regarding a friend who had been injured on the job using a particular type of machine, the lawyer referred the caller to another Madison lawyer who had a reputation for handling injuries involving that type of machine. Adams received at least one new client during the observational period as a referral from another lawyer because Adams handled a particular type of case that relatively few lawyers were willing to handle.

While probably the most common reason that lawyers referred cases elsewhere was that they simply did not handle a particular type of case, another very frequent reason for referring a caller to a different lawyer was a conflict of interest. In our practitioner survey, we asked lawyers what percentage of potential clients they referred to more specialized lawyers, to less specialized lawyers, or because of a conflict of interest. We estimate that over half of referrals are to a more specialized lawyer, while a third of referrals reflect conflicts. It is easy to see how conflicts might arise. One type of conflict situation is common among the significant number of lawyers in the survey who handle insurance defense work; if a potential 
contingency fee client has a claim against an insurer that the lawyer has represented, the lawyer must decline representation. Frequently, the lawyer refers the caller to another lawyer who has not represented that insurer. Another conflict situation arises for contingency fee specialists who are members of relatively large general practice firms; those lawyers have a measurable probability of having partners who have or do represent a potential defendant (particularly in a premises liability case or a professional malpractice case). When conflicts like these arise, lawyers can simply decline representation or suggest other lawyers; the latter course of action appears common among the lawyers in the Wisconsin study.

Some lawyers report receiving cases from other lawyers after the first lawyer has at least partially "worked up" the case and tried to obtain a settlement. When the initial lawyer realizes that the case is beyond his or her skill, expertise, or resources, that lawyer will contact someone with a reputation for handling the type of case in question. Not surprisingly, the receiving lawyers are often critical of what the first lawyer had done. Lawyers who handle referrals prefer to receive the case at the beginning so that they need not undo things that someone less familiar with the area might have done in error.

As it turns out, there are relatively few lawyers or firms in Wisconsin that depend heavily on paid referrals. ${ }^{21}$ There is at least one firm that we identified that describes itself as primarily depending on referrals from other lawyers ("We rarely take cases that don't come from other lawyers"), and which usually pays a referral fee. That firm jealously guards its relationships with referring lawyers, to the point that, if a client previously referred by another lawyer directly contacts the firm about a new case, the firm will ask the client to go back through the original lawyer. As part of the practitioner survey, we asked lawyers to name the others who had been the recipients of the respondent's two most recent referrals, and this firm showed up most often (representing almost 10 percent of the names provided). Three other firms combine to constitute another 10 percent of the referrals mentioned; two of those firms are well-known for handling large cases, and the third has a reputation for expertise in some very specific types of cases. However, 45 percent of the mentions appeared only once. ${ }^{22}$

Some lawyers report specific activities aimed at obtaining referrals from other lawyers. Some lawyers advertise specific specialties (e.g., legal malpractice) in periodicals aimed at other lawyers. Others seek out opportunities to speak before bar groups about developments in their specialty (cf. Daniels \& Martin 1999:387). Some lawyers emphasize mutual referral networks, where they received referrals from lawyers who do not handle personal injury or social security or worker's compensation and refer other cases back to those same lawyers.

Before turning to other sources, there is one interesting point about paid referrals that is worth noting. Paid referrals are controversial, and states consider it a violation of professional rules of ethics. However, there is an 
argument to be made that referrals work largely to the client's benefit because the referring lawyer can serve as the client's expert alter ego (see Hay 1996). If one presumes that the client's interest is to maximize the settlement, this same interest accrues to the referring lawyer who stands to receive a percentage of any ultimate fee. Note that on a single-case basis, this may not be the profit-maximizing outcome for the lawyer who is actually handling the case ("working the case"); as economic analysis has shown (Johnson 1981; Rosenthal 1974; Miller 1987; Kritzer 1991:63-64), the lawyer doing the work wants to maximize his or her hourly return, and this often happens at a point that is not optimal for the client who is paying on a percentage basis. The problem for the typical client is that he or she lacks the information to assess a proposed settlement. This problem is much less the case for a referring lawyer (one who is not investing his or her own time and hence prefers the same outcome as the client rather than the lawyer working the case). While the referring lawyer may not be formally included in the decision to settle, that lawyer will be aware of the payment that is ultimately received. If the lawyer working the case wants future referrals from the referring lawyer, the former wants to be sure that the referring lawyer is satisfied with the outcome, with the result that the lawyer handling the case will not want to underperform. This need to satisfy the relatively knowledgeable referring lawyer serves to check the potential conflict of interest between the lawyer working on the case, and the client.

\section{F. EXISTING (AND REPEAT) CLIENTS}

Overall, in our Wisconsin survey, the lawyers reported that an average of 19 percent of their contingency fae clients are "existing clients." This category captures two very different situations, one for contingency fee specialists outside a broader firm structure and one for mixed practice lawyers and contingency fee specialists within a general practice firm. The idea that a firm offering a range of services to its clients would potentially service contingency fee cases for existing clients is not surprising, particularly in smaller communities where firms must offer a range of services to survive. In Madison, and no doubt elsewhere, there are twenty to fifty law firms that have significant corporate or business clienteles and at the same time include small groups of lawyers who are contingency fee specialists. Often these specialists rely very heavily on what amounts to an internal referral network for many of their clients. Those lawyers who are not personal injury plaintiffs' specialists report that an average of 23 percent of their contingency fee clients are "existing clients."

Lawyers who describe themselves as specializing in personal injury plaintiffs' work report than only an average of 11 percent of their cases come from "existing clients." For these lawyers, this usually means that the clients are repeaters; that is, the lawyer had previously represented the client (or a member of the clients' immediate family) on a personal injury matter. 
The general image of personal injury lawyers is that they represent a succession of one-shot clients. The reality appears to be that, for most of these lawyers, the repeat client is in fact a measurable part of their work. In two of the firms included in the observational part of the research, at least one of the contingency fee cases resolved during the month involved a repeat client. ${ }^{23}$ In both cases, while the claims were quite small, the lawyer greatly valued working on behalf of the repeat client because the lawyer believed that the repeat client was particularly likely to be a source of future work, either from the client him or herself or from persons referred by the repeat client. One of the interviewees summed up the role of repeat clients: "Clients come back. I just had a client come back. I settled his auto case and now he got hit by a car as a pedestrian. You find, and this seems very odd, but you find that the same people have accidents over and over; I don't know if they are looking for trouble, or if they are accident prone, but it happens."

Not surprisingly, lawyers want to facilitate this type of repeat business. Beyond delivering a good result and creating a positive impression, lawyers do many of the standard types of things businesses do to maintain client/ customer contact: mail out Christmas cards, send out newsletters, notify clients of developments that may be of interest to them and the like.

\section{G. CLIENT REFERRALS}

Besides returning when a new matter arises, satisfied clients produce additional cases by referring others in need of legal services to the lawyers they had previously used (cf. Daniels \& Martin 1999:383-84). Referrals from prior or existing clients tend to be the largest single source of new clients, both for all lawyers and for personal injury plaintiffs specialists. Based on the survey of Wisconsin practitioners, we estimate that an average of about a quarter of all contingency fee clients come as referrals from prior or existing clients (the next highest source provides about one fifth of such clients). Of the twenty cases described during the semi-structured interviews, eight (40 percent) came as client referrals.

The importance of client referrals came up repeatedly during the observation, and during the interviews. For example, one of the lawyers who was observed (Brown) repeatedly stated how much he valued receiving clients via referrals, taking an extra-close look at potential clients who came as referrals before declining any such clients; on occasion this led Brown to accept some marginal cases he might otherwise have declined. Whenever Brown was contacted by someone referred by a prior client, he made an effort to communicate his appreciation to the referrer. Brown's view was that a former client who has made one referral is likely to make future referrals, and whatever he can do to encourage this practice (e.g., taking the referred case even if it is marginal, and expressing his appreciation) he will try to do. The importance of referrals to Brown was nicely illustrated by his "exit procedure": After handing the client a check from a decision or 
settlement, Brown would then hand the client one of his cards and say, "Hopefully you won't need me again ... [but] if you know someone who does, please send them in."

\section{H. COMMUNITY CONTACTS}

Perhaps the most traditional way for lawyers serving the "personal plight" (Heinz \& Laumann 1982) sector of the legal market place is by building up community contacts (Seron 1996: 52-56; Van Hoy 1997a). At the simplest level, this starts with friends and family who find that they need legal services. At the other extreme, it may be a lawyer who has achieved local prominence, often by having served in a visible public office such as district attorney, or as a member of the state legislature (Van Hoy 1997a; Barber 1965:67-115).

We estimate, based on the survey of Wisconsin practitioners, that only about 15 percent of clients come through community contacts (regardless of whether or not the lawyer is a personal injury plaintiffs' specialist). ${ }^{24}$ Both the observation and the interviews show that lawyers see community visibility and the resulting community contacts as important sources of clients. One of the lawyers observed, Mr. Clark, made a special effort to develop contacts through labor organizations, offering to speak to various labor groups, and willingly accepting telephone calls on very marginal matters from members of union organizations. Over the month that this article's senior author observed this practice, Clark several times remarked that he "gives out a lot of free advice" to union members; Clark typically made such a comment after an extended telephone conversation that he had realized almost immediately would not need lead to a fee-generating case. Nevertheless, he continued to devote significant time to these calls in the hopes that someone from one of the unions will call him should a large claim come up.

Both Adams and Brown (the other two lawyers we observed) were very active in community- and local-service organizations. Adams served as an officer of one such organization. Brown made a very specific effort to be seen in the community by circulating among various local restaurants (he was based in a town outside Madison) for lunch. He stated very explicitly that he did this to be seen so that, should someone have a case, they would be more likely to think of him.

These kinds of contacts were frequently mentioned by interview respondents: for example, speaking before unions and community groups, serving on boards of directors of service organizations, giving scholarships, and sponsoring Little League teams. In one sense these activities are a form of advertising, but they are more of an institutional ad rather than one that is targeted to a specific market or clientele. The idea, as one interview respondent expressed, is to have the lawyer's or firm's name associated with positives in the community with the hope that it will pay off over time. One 
lawyer described a senior partner who was very active in a variety of community settings as "a schmoozy sort of guy" who makes a lot of very good contacts for the firm. Another lawyer commented that "I have a lot of activities that have nothing to do with practicing law, but it exposes me to a lot of contacts who hopefully see me as a person to come to when they need a lawyer."

Community contacts include a variety of other types of sources: for example, referrals from medical providers, public officials, and law enforcement personnel. Clark received a number of referrals from political and legal officials. His practice was a mixed court-practice that included criminal and family cases in addition to civil litigation; a significant portion of his cases came as referrals from the contacts he had cultivated in the courthouse setting. During the month of observation, one of the personal injury clients who went to Clark obtained his name from a local prosecutor; another new personal injury client obtained Clark's name from a local judge; and one of his new criminal clients obtained his name from a local political figure.

Other potential referral sources are medical providers (see Daniels \& Martin 1999:390-91). Lawyers may try to initiate contacts with medical providers who might be good referral sources. Some lawyers report contacts from medical providers who are interested in a mutual referral system because the medical provider frequently comes in contact with accident victims. Even without mutual referrals, medical providers can be sources of clients; two of the twenty cases described during the semi-structured interviews came from such referrals; several respondents to the structured survey specifically mentioned medical providers under the "other" category of client sources.

\section{OTHER SOURCES}

There are a variety of other sources from which clients might come. Referrals from members of a lawyer's family or social friends is one such source. Occasionally a client might obtain the lawyer's name from a referral service operated by the state or local bar association, or from a lawyer referral service operated by some other type of organization (e.g., a labor union, an employer, or a social service agency). A few clients might find the lawyer's name in a specialized directory such as Martindale-Hubbell or a state bar directory. None of these appears to be a major source of clients.

\section{SYSTEMATIC VARIATION AMONG CLIENT SOURCES}

Clearly there is substantial variety in the ways in which contingency fee clients reach a particular lawyer's office. Lawyers specializing in personal injury plaintiffs' work are slightly more likely to rely upon nontraditional, advertising-based sources while other lawyers are slightly more likely to 
draw from an existing client base. However, both groups are most likely to draw on sources such as referrals from prior clients and from other lawyers, and from community-based contacts. Are there other variables that might account for systematic variation among client sources? We explored the possible influence of several variables: years in practice, size of community, gender, and firm versus solo practice.

\section{A. YEARS OF PRACTICE}

Conversations with several lawyers suggested the hypothesis that reliance on advertising might decrease as a lawyer built up his or her reputation and a client-referral network comprising prior clients, community contacts, and other lawyers. The logic of this was simply that one could buy name exposure through advertising and that this could be a useful way to get a practice started. However, we could find no evidence that those who relied heavily upon advertising for clients differed in years of experience from those who did not.

In fact, we could find little evidence of any impact of years in practice. There did seem to be a break at around ten years of practice; those with less than ten years reported an average of about 20 percent of clients coming as referrals from other clients, compared to 27 percent for those in practice for more than ten years. Further analysis showed that there was no such difference for personal injury specialists; for lawyers who were not PI specialists, those with less than ten years of experience obtained an average of 18 percent of clients as referrals from prior clients while the comparable figure for those in practice at least ten years was 27 percent. $^{25}$

\section{B. SIZE OF COMMUNITY}

Research has shown that the nature of legal practice differs between large urban and rural communities (Landon 1988, 1990). Does this translate into differences in sources of contingency fee clients? Surprisingly, and to some degree in contrast to the situation in Indiana (Van Hoy 1997a) and Texas (Daniels \& Martin 1999), the answer is that it does so only in relatively small ways. For example, one might expect that lawyers in large urban communities would be more likely to rely upon impersonal sources such as advertising. However, overall among the lawyers in the survey, there are no statistically significant differences in the use of advertising based on community size, varying between 11 and 17 percent across four categories of community size. ${ }^{26}$ More interestingly, adding a control for whether or not the lawyer is a personal injury specialist produces a statistically significant difference for those who are not PI specialists, but it is the lawyers in smaller communities who rely more on advertising (11-12 percent of contingency fee clients versus about 6 percent for those in larger communities). ${ }^{27}$ 
The one other difference that showed up clearly related to community size (and which held up after controlling for whether or not the respondent was a personal injury specialist) is that, as community size decreased, the average percentage of contingency fee clients coming as referrals from other lawyers decreased. ${ }^{28}$ This probably reflects varying degrees of specialization in the bar, with more lawyers in smaller communities engaged in general practice and hence less likely to refer out clients generally (and contingency fee clients more specifically); ${ }^{29}$ in fact, in communities of 100,000 or larger (including Milwaukee and its suburbs), only 16 percent of the respondents described themselves as being in general practice, as compared to 47 percent of the respondents from communities under 25,000. Also, in smaller communities, relatively few attorneys do insurance defense work (because insurance companies tend to retain firms in larger cities, even to handle cases coming from smaller, outlying communities), and hence the problem of conflicts of interest that lead some attorneys to refer cases to other lawyers is less common. ${ }^{30}$

\section{GENDER}

Only about 13 percent of the practitioner survey respondents were women. ${ }^{31}$ Women appear somewhat more likely than men to obtain contingency fee clients as referrals from other lawyers or as pre-existing (or prior clients), while obtaining fewer clients as referrals from other clients or from community contacts. ${ }^{32}$ Advertising plays essentially the same role as a source of clients for both men and women. The pattern remains the same if we add controls for whether or not the lawyer was a personal injury specialist. ${ }^{33}$ A part of these gender-based patterns might be attributable to the fact that the women in the sample have tended to be in practice for shorter periods than the men $(80$ percent of the men had been in practice ten or more years, as compared to only 59 percent of the women), ${ }^{34}$ but recall that years in practice related only to referrals from other clients. In light of this information, we do not have an explanation for this gender-related pattern.

\section{PRACTICE SETTING}

Only about 15 percent of the respondents reported being in solo practices. ${ }^{35}$ Solo practitioners are more likely than firm practitioners to obtain contingency fee clients as referrals from other clients or as existing clients; firm practitioners are more likely than solo practitioners to obtain clients as referrals from other lawyers and through community connections. ${ }^{36}$ There is no difference in the role of advertising depending on practice setting.

Some shifts in these patterns occur when we control for whether or not the respondent is a personal injury specialist. Among those who are not PI specialists, the differences between solo and firm practitioners decrease while increasing for PI specialists with regard to prior or existing clients and 
community contacts. Furthermore, while the role of advertising did not differ previously, it differs with the controls, and in diverging ways. A larger proportion of the clients of PI specialists in firms come in response to advertising than for solo practitioners; however, among non-specialists, advertising is a more important source of clients among solo practitioners than it is among firm practitioners.

\section{E. SUMMARY}

We found a number of relationships that served to specify somewhat lawyers' sources of cases. Some of the relationships are as one would expect, while others are more difficult to explain. However, none of the relationships is strong enough to modify substantially the thrust of our findings: Lawyers rely most heavily upon word-of-mouth referrals and prior or existing clients for their contingency fee cases, and this pattern is tied to our opening suggestion that maintaining a positive reputation is a crucial consideration for contingency fee practitioners. Few lawyers obtain more than a relatively small fraction of their contingency fee clients primarily as a result of advertising in the Yellow Pages, direct mail, or the media. Let us now turn to the implications of these findings.

\section{THE ROLE OF REPUTATION IN CLIENT/CASE ACQUISITION}

One theme binds a number of the sources of contingency fee clients together: the importance of a lawyer's reputation (see also Van Hoy 1997a:24-25; Daniels \& Martin 1999:382). In order for a lawyer to secure clients through referrals from other lawyers, prior clients, and community contacts, or through repeat business from existing or prior clients, a lawyer must have a reputation that he or she will provide good service to clients. Good service can involve any of a variety of elements: responding well to client contacts (i.e., returning telephone calls), keeping the client abreast of developments, interacting positively and effectively with the client, and delivering a result that the client sees as satisfactory and continues to see as satisfactory over time. In a case involving the payment of money damages, which by necessity is almost always the case when the lawyer is paid on a contingency fee basis (Kritzer 1987), the result is gauged in terms of the payment the client receives (and possibly how long it takes to secure that payment).

As noted previously, one of the standard criticisms of the contingency fee system is that the lawyers' interests diverge from the clients' interests in ways that would appear to lead lawyers to want to settle many cases quickly and cheaply (see Rosenthal 1974; Johnson 1980-81; Miller 1987; Kritzer 1991:100-5). A simple example makes it clear why this might happen. A lawyer handling a case with a maximum payment of $\$ 25,000$ comes out better by settling the case for $\$ 10,000$ after ten or twenty hours of work 
(investigating the claim, collecting documentation, drafting a demand letter, and negotiating a settlement) than by taking the case to trial and winning $\$ 25,000$ after 100 or 150 hours of work. With the settlement, a lawyer receiving a 25 percent fee earns $\$ 125$ to $\$ 250$ per hour; with the trial, even with a 33 percent fee, the lawyer earns $\$ 55$ to $\$ 83$ per hour. ${ }^{37}$

On its face, this incentive structure is a powerful criticism of the conflicts inherent in a contingency fee arrangement. While the analysis may turn out quite differently for very large cases, ${ }^{38}$ most cases handled by most lawyers are in the range that this example used. ${ }^{39}$ However, the apparent conflict of interest neglects the need of the lawyer to generate a stream of cases. While analyses of contingency fees have typically considered the incentives involved in a single case with a single client, the economically rational contingency fee lawyer should be concerned about the return across a portfolio of cases rather than the return from any specific case. Central to achieving a good return is the need to maintain a good portfolio of cases. Our analysis shows clearly that the key to attracting clients with good cases is having a good reputation, particularly among other lawyers and former clients. In support of this conclusion, other analyses from this study (see Kritzer 1998a) show that lawyers do not simply manipulate clients in order to maximize their own short-term economic benefits; they regularly accept fee reductions and push cases beyond the point that their own immediate economic interests would suggest was rational. Furthermore, the lawyers are extremely attentive to they ways their clients see what has been accomplished on their behalf.

It is easy to imagine that the lawyers who make these referrals are able to distinguish between their colleagues who deliver results for their clients and those who are more concerned about their own interests. How is this the case for former contingency fee clients (who might recommend the lawyer to friends, family members, or co-workers, or who might return with a new case themselves)? Very simply, clients talk about their experiences and compare their experiences with those of their friends. A client who obtained a settlement of two or three thousand dollars for a serious injury such as a broken leg is likely to hear things from others that suggest that the injury was substantially undercompensated. Contingency fee lawyers want their clients to be satisfied with the result the lawyer obtained on their behalf; more importantly, the lawyers want the clients to stay satisfied. A lawyer who settles cases too cheaply will have trouble maintaining the reputation necessary to create the flow of potential clients that is in his or her long-term interest.

To summarize, we find that most lawyers handling contingency fee cases rely upon relatively traditional sources - referrals from other lawyers and past clients, existing and repeat clients, and community involvement - to produce an ongoing stream of clients. Even most lawyers who make very heavy use of advertising do not obtain the majority of their contingency fee clients directly from their advertising. Relatively few lawyers rely 
predominantly on advertising (i.e., the media, the Yellow Pages, and/or direct mail). The reliance on referrals, repeat business, and community involvement means that the key element in client acquisition for most lawyers is building and maintaining a reputation. The importance of the lawyer's reputation for maintaining a profitable portfolio of contingency fee cases creates incentives for lawyers to deliver positive results for their clients, and these incentives serve to counteract the pressures that would appear to encourage lawyers to settle cases with more of an eye on their own immediate bottom lines than on the interests of their clients.

Let us conclude with a brief discussion of the policy implications of our findings. Marc Galanter (1998) has described the phenomenon of what he labels "legal legends": stories about the legal system that spring from a grain of truth but that become embellished and repeated as motivations for major legal reforms. Central to the images associated with many legal legends are "ambulance-chasing" lawyers who employ techniques such as direct mail solicitation and extensive media advertising to attract clients to their doors. What this analysis shows is that very few lawyers, at least in Wisconsin, employ such techniques and that relatively few clients are brought to lawyers' offices by these methods even for the lawyers who use them! Other analyses from this study (Kritzer 1997b) show that those lawyers who employ aggressive techniques to attract potential clients to their offices actually turn away the vast majority (on the order of 90 percent) of those who contact them.

While common sense would seem to suggest that aggressive client-seeking should increase claims-making and litigation, there is no systematic evidence that this is the case. Relatively few claimants or litigants obtain counsel as a result of aggressive client-seeking actions of a small segment of the legal profession. Regardless of whether or not the media advertising or directmail solicitation led an injury victim to retain one of the lawyers employing these methods, the advertisements and mailings may serve to alert victims to compensation to which they might be entitled. While tort litigation critics allege that Americans are overlitigious, other observers have pointed out that Americans frequently fail to seek compensation to which they are entitled (see Abel 1987). In the survey of direct-mail recipients (Sweet 1997), fewer than 5 percent of the respondents actually retained a lawyer who sent them a letter, but 40 percent did hire a lawyer; for some fraction of these persons, the mail they received from lawyers probably helped them decide whether or not to contact a lawyer. The survey asked whether or not the letter was helpful, and 10 percent of the respondents indicated that it was (14 percent of those with serious injuries).

Many states have implemented, or at least considered, rules to bar attorneys from making contact with potential personal injury clients for thirty days after the injury occurs. Ostensibly this is to protect injured parties from unscrupulous lawyers who are hungry for fees. However, to our knowledge, no state imposes similar restrictions on tortfeasors' insurance 
companies. About 40 percent of the respondents in the survey of direct-mail recipients reported that the "other party's insurance company" initiated contact with them, and that almost three quarters of those contacts came within seven days of their injuries. Furthermore, 36 percent of those contacted were offered settlements within thirty days of the injuries. In assessing the impact of limitations on lawyers' client-seeking activities, it is important to determine whether or not the information provided through those activities has positive benefits for personal injury victims, and how those positive benefits balance out against the supposed negatives.

HERBERT M. KRITZER is Professor of Political Science and Law at the University of Wisconsin-Madison. He is the author of four books, the most recent of which is Legal Advocacy: Lawyers and Nonlawyers at Work (University of Michigan Press 1998). In addition to his research on contingency fee legal practice, he is currently working on a study of Supreme Court decision making which relies on the concept of "legal regimes" as a means of incorporating law into statistical models of the justices' votes.

JAYANTH K. KRISHNAN is a doctoral candidate in the department of political science at the University of Wisconsin-Madison. He holds a B.A. and J.D. from Ohio State University. He currently teaches American and comparative politics at the University of Wisconsin-Milwaukee.

\section{NOTES}

1. Conflicts of interest between lawyers and clients created by fees are by no means limited to the contingency fee structure (see Johnson 1980-81; Silver 1992; Kritzer 1991:105-111, 199).

2. The losses can arise if the case returns no fee, returns an unexpectedly low fee because the amount at stake turns out to be less than anticipated (or problems in the case lead to an unfavorable compromise), or requires significantly more time and effort than the lawyer had anticipated.

3. In fact, lawyers take cases from something fewer than 50 percent of the potential clients who contact them for representation on a contingency basis; interestingly, and not surprisingly, those lawyers who are most aggressive in seeking clients end up turning away a very large proportion of those people who contact them, as much as 90 percent or more (see Kritzer 1997a, 1997b; see also Van Hoy 1996).

4. The 511 represented an estimated response rate of $47.7 \%$; see the Appendix for details.

5. This work is heavily, but by no means exclusively, personal injury plaintiffs' representation.

6. We use the term "included" here because a significant number of lawyers reported two or more sources tied as producing the largest proportion (the 471 respondents produced 639 responses).

7. Daniels and Martin report that few Texas lawyers use direct mail, or at least will admit to using it (1999:389).

8. For an analysis of the factors influencing lawyers' decisions to advertise, see Bowen (1995b). 
9. While this advertising is primarily television and radio, it also includes classified advertisements, billboards, and other print advertising.

10. This was in response to an open-ended question. Compare these figures to those from a 1996 survey in Florida, which found that only 3\% of the respondents who had retained a lawyer had learned of that lawyer from electronic (i.e., television or radio) advertising (Magid 1997:2).

11. In his study of franchise law firms, Van Hoy (1997:54) found that the firms that rely heavily on advertising had to spend time sorting out significant numbers of "undesirable" clients.

12. In smaller communities, local cable channels provide a medium somewhere between radio (less audience-specific) and television (more geographically targeted).

13. Van Hoy (1997a) and Daniels and Martin (1999:389-90) found that media advertising was dominated by a small number of firms in both Indiana and a number of cities in Texas.

14. Habush buys time during radio broadcasts of Green Bay Packer football games ("You need a winning team of lawyers").

15. This is also true of radio. In one firm that was involved in the observational part of the research, the lawyers were negotiating with a radio station for a series of ads; one of the problems they encountered was the question of "how much is enough?" For advertising to create visibility, it takes a sustained program, and it can be very difficult to gauge the payoffs accurately (compare to Van Hoy 1997b:12-13).

16. See Van Hoy (1997a) and Daniels and Martin (1999:389-90) for descriptions of generally similar patterns in Indiana and Texas.

17. The 1996 Florida survey found that $15 \%$ of the respondents who had used lawyers had "learned about their lawyer from the telephone book or Yellow Pages" (Magid 1997:2).

18. Of the twenty cases described during the semi-structured interviews, three $(15 \%)$ came referrals from lawyers in other firms.

19. Only about $4 \%$ of the respondents in the practitioner survey indicated that they referred no potential contingency fee cases to other lawyers.

20. For an economic analysis of referral fees, see Hay (1996), who argues that it can often be to the client's advantage for a lawyer to make a paid referral of a case, even if the client has to bear part of the cost of the referral.

21. This appears to contrast somewhat to the situations described by Van Hoy (1997a) and Daniels and Martin (1997, 1999:385-87) for Indiana and Texas, respectively. The apparent absence of paid referrals in Wisconsin cannot be attributed to formal restrictions; the Wisconsin Supreme Court rules governing attorney fees explicitly permit sharing of fees, provided either that the division is proportional to the services performed or that it is by "written agreement with the client and each lawyer assumes joint responsibility for the representation" (Rule 20:15:5(e)).

22. Daniels and Martin describe the phenomenon of lawyers who advertise cases and then broker them to other lawyers (1999:385-88). We could not find evidence that this practice was a significant source of clients for Wisconsin lawyers, but some lawyers do receive at least some cases this way.

23. One of these repeat clients was, if one counts other members of his immediate family, a multiple repeater (the case observed by the senior author of this article was at least the fourth involving this client or other immediate members of his family).

24. Three of the twenty cases $(15 \%)$ discussed in the interviews came from friends in the community; another two cases were referred by medical providers, a community source that was not explicitly included in the survey. 
25. We also looked to see whether or not practice setting might obscure the impact of years of experience. We split the sample into three groups, depending on size of firm (one to three, three to nine, and more than nine lawyers). The only significant pattern that showed up at all when we did this was that lawyers in the larger firms who had less than ten years experience were less likely to obtain clients as referrals from prior clients.

26. The four categories are Milwaukee and its suburbs, other communities with populations of 100,000 or more, communities between 25,000 and 99,999 , and communities with fewer than 25,000 residents.

27. $\mathrm{F}=3.246(\mathrm{df}=3,308), \mathrm{p}=.022$.

28. $\mathrm{F}=5.694(\mathrm{df}=3,458), \mathrm{p}<.001$.

29. In their studies in Texas and Indiana, Daniels and Martin (1997) and Van Hoy (1997a) place emphasis on substantive specialities. Our study found much less substantive emphasis (and this was true regardless of whether we looked at all respondents or only those who identified themselves as personal injury plaintiffs' lawyers). For example, in the survey only four respondents reported that more than 75 percent of their practice consisted of product liability cases (only two said their practices were 100 percent product liability), and only six said that they did 75 percent or more medical malpractice (three reported 100 percent medical malpractice); of course, it may be that specialization falling along some other dimension (e.g., type of injury) is more common, but we found no evidence of that from any of our data sources (none of the lawyers participating in the semistructured interviews reported specializations consuming the bulk of their practices). Whether the differences in Wisconsin reflect sampling strategies used in the research, or differences among the states in the organization of legal practice, is not clear.

30. Even after taking into account the higher likelihood of general practice in the smaller communities, lawyers in those communities were much less likely to be insurance defense specialists than were lawyers in large communities (10\% versus 20 to $25 \%$ ).

31. This percentage is the same for personal injury specialists and nonspecialists.

32. The differences in means between men and women for the latter two sources are statistically significant while for the former two the statistical tests are borderline.

33. Because of the small number of women, only one of the statistical tests achieved significance after adding controls.

34. The mean years of practice for men was 18.6 , compared to 12.4 for the women.

35. Note that this contrasts with $42 \%$ of Wisconsin's private practice lawyers in solo practice as of 1991 (Curran \& Carson, 1994: 226). While this may seem to suggest sample bias toward firm practitioners, prior research has found that solo practitioners are under-represented among litigators, and the degree of underrepresentation is consistent with the figures in the Wisconsin survey (see Kritzer 1990:44-45).

36. T-tests show that all of these differences are statistically significant.

37. A variable contingency fee percentage is relatively common in Wisconsin (see Kritzer 1998b:286-88).

38. If the case is big enough, the recovery will increase enough with the additional time investment to more than offset that investment (see Kritzer, et al. 1985).

39. The practitioner survey asked respondents to provide low and high figures for their initial evaluations of each of the cases for which they provided information. The median of the low figure was $\$ 10,000$, and the median of the high figure was $\$ 30,000$.

40. After removing government lawyers and others clearly not engaged in contingency fee practice, the sample included a total of 1,850 target respondents. 
41. We say "estimated" because the survey was mailed to all litigation section members in private practice, many of whom we knew would not handle cases on a contingency fee basis. We included with the survey a postcard that respondents could return indicating that they did not do any contingency fee work; 1,192 of the 1,850 lawyers who received the questionnaire provided some kind of response. In order to estimate the number of contingency practitioners among the 658 who did not respond, a research assistant telephoned about 200 law offices and asked whether or not the lawyer handled cases on a contingency fee basis. Combining these elements, we estimate that 1,072 of the 1850 lawyers receiving the questionnaire did at least some contingency fee work.

42. To further frame the sample of cases, the survey asked only about cases that the lawyer had closed during the preceding twelve months (or fiscal year if that was easier).

43. The first two lawyers we contacted about observing in their offices said "yes," number three said "no," and number four said "yes."

44. In the interviews with contingency fee practitioners, this article's senior author solicited names of defense lawyers and adjusters who might be contacted. From the defense lawyers, the interviewer solicited names of additional adjusters, focusing on individuals who had recently retired (on the assumption that they would feel less constraint than would individuals who were currently employed by insurance companies).

\section{REFERENCES}

ABEL, RICHARD L. (1987) "The Real Tort Crisis - Too Few Claims," Ohio State Law Review 48:443-67.

AUERBACH, JEROLD S. (1976) Unequal Justice: Lawyers and Social Change in Modern America. New York: Oxford Univ. Press.

BARBER, JAMES DAVID (1965) The Lawmakers: Recruitment and Adaptation to Legislative Life. New Haven: Yale Univ. Press.

BERGSTROM, RANDOLPH E. (1992) Courting Danger: Injury and the Law in New York City, 1870-1910. Ithaca, N.Y.: Cornell Univ. Press.

BIEDERMAN, CHRISTINE (1996) "Families of Valujet Crash Victims Find Lawyers Ignore Solicitation Ban," New York Times 4 June:A13.

BLUM, ANDREW (1987) "Deaths in the Snow Lead to Suits:'You Don't Take Off in a Storm," National Law Journal 30 November:3.

BOWEN, LAUREN (1995a) "Advertising and the Legal Profession," Justice System Journal 18:43-54.

(1995b) "Attorney Advertising in the Wake of Bates v. State Bar of Arizona (1977): A Study of Judicial Impact," American Politics Quarterly 23:461-84.

BRICKMAN, LESTER (1989) "Contingent Fees without Contingencies: Hamlet Without the Prince of Denmark?" UCLA Law Review 37: 29-137.

CARLIN, JEROME E. (1962) Lawyers on Their Own: A Study of Individual Practitioners in Chicago. New Brunswick: Rutgers Univ. Press.

CURRAN, BARBARA A., and CLARA N. CARSON (1994) The Lawyer Statistical Report:

The U.S. Legal Profession in the 1990s. Chicago: American Bar Foundation.

DANIELS, STEPHEN, and JOANNE MARTIN (1997) "Client Quest: Markets, Professional Ideology, and the Plaintiffs' Bar in Texas," Researching Law: An ABF Update $8(4): 4-5,10$.

- (1999) "'It's Darwinism - Survival of the Fittest:' How Markets and Reputations Shape the Ways in which Plaintiffs' Lawyers Obtain Clients," Law \& Policy 21:377-99. 
DAVIS, ANN (1995) "The Earth Breathes Fire, Scorches Lawyers," National Law Journal 10 April: A10.

GALANTER, MARC (1998) "An Oil Strike in Hell: Contemporary Legends about the Civil Justice System," Arizona Law Review 40:717-52.

HAY, BRUCE L. (1996) The Economics of Lawyer Referrals. Discussion Paper No. 203. Cambridge: Center for Law, Economics, and Business, Harvard University.

HEINZ, JOHN P., and EDWARD O. LAUMANN (1982) Chicago Lawyers: The Social Structure of the Bar. New York: Russell Sage Foundation.

HOROWITZ, MICHAEL (1995) "Making Ethics Real, Making Ethics Work: A Proposal for Contingency Fee Reform," Emory Law Journal 44:173-211.

JOHNSON, EARL (1980-81) "Lawyers' Choice: A Theoretical Appraisal of Litigation Investment Decisions," Law \& Society Review 15:567-610.

KARSTEN, PETER (1998) "Enabling the Poor to Have Their Day in Court: The Sanctioning of Continency Fee Contracts, a History to 1940," DePaul Law Review 47:231-60.

KRITZER, HERBERT M. (1998a) "Contingent-Fee Lawyers and Their Clients: Settlement Expectations, Settlement Realities, and Issues of Control in the LawyerClient Relationship," Law \& Social Inquiry 23:795-821.

- (1998b) "The Wages of Risk: The Returns of Contingency Fee Legal Practice," DePaul University Law Review 47:267-319.

- (1997a) "Holding Back the Floodtide: The Role of Contingent Fee Lawyers," Wisconsin Lawyer 70(3):10-13, 62-64.

- (1997b) "Contingency Fee Lawyers as Gatekeepers in the Civil Justice System," Judicature 81:22-29.

_ (1994) "Lawyers' Fees and the Holy Grail: Where Should Clients Search For Value?" Judicature 77:187-90.

- (1991) Let's Make a Deal: Understanding the Negotiation Process in Ordinary Litigation. Madison: Univ. of Wisconsin Press.

- (1990) The Justice Broker: Lawyers \& Ordinary Litigation. New York: Oxford Univ. Press.

- (1987) "Fee Arrangements and Negotiation: A Research Note," Law \& Society Review 21:341-48.

KRITZER, HERBERT M., WILliAM L. F. FELSTINER, AUSTIN SARAT, and DAVID M. TRUBEK (1985) "The Impact of Fee Arrangement on Lawyer Effort," Law \& Society Review 19:251-78.

LANDON, DONALD D. (1990) Country Lawyers: The Impact of Context on Professional Practice. Westport, Conn.: Praeger Publishers.

- (1988) "LaSalle Street and Main Street: The Role of Context in Structuring Law Practice," Law \& Society Review 22:213-36.

LYONS, DAVID, and ANDREW BLUM (1996) "Were ValuJet Families Solicited? Two Lawyers Accused," National Law Journal 3 June:A4.

MACLACHLAN, ClAUdia (1993) "Mobile Response to Amtrak Crash," National Law Journal 11 October: 1.

MAGID, FRANK N., ASSOCIATES (1997) "Attitudes and Perceptions of Lawyer Advertising in Florida: An Executive Summary of Phase I Results." Unpublished paper of the Florida Bar Ethics Department, on file with author.

MILlER, GEOFFREY P. (1987) "Some Agency Problems in Settlement," Journal of Legal Studies 16:189-215.

POWELL, MICHAEL J. (1988) From Patrician to Professional Elite: The Transformation of the New York City Bar Association. New York: Russell Sage Foundation.

REED, JOHN P. (1969) "The Lawyer-Client: A Managed Relationship?" Academy of Management Journal 12:67-80.

ROSENTHAL, DOUGlas E. (1974) Lawyer and Client: Who's in Charge? New York: Russell Sage Foundation. 
SERON, CARROLL (1996) The Business of Practicing Law: The Work Lives of Solo and Small-Firm Attorneys. Philadelphia: Temple Univ. Press.

SILVER, CHARLES (1992) "Unloading the Lodestar: Toward a New Fee Award Procedure," Texas Law Review 70:865-970.

STANLEY, AlESSANDRA (1991) "Bronx Crash, Then Contest of Lawyers," New York Times 17 June:B1.

SWEET, JAMES A. (1997) Report on Survey of Accident Victims. Madison: Univ. of Wisconsin Survey Center for the Wisconsin Board of Attorneys Professional Responsibility.

TAYLOR, GARY (1986) "Army, Lawyers Feud Over Crash; Allegations of Solicitation," National Law Journal 2 June:3.

VAN HOY, JERRY (1997a) "Getting Clients: Supply and Demand Among Plaintiff's Personal Injury Attorneys in Indiana." Paper presented at the annual meeting of the Law \& Society Association, 29 May-1 June, St. Louis, Missouri.

(1997b) Franchise Law Firms and the Transformation of Personal Legal Services. Westport, Conn.: Quorum Books.

- (1996) "Plaintiff's Personal Injury Attorneys in Indiana: Overzealous Advocates or Principled Protectors of the Individual?" Paper presented at Law \& Society Association Annual Meeting, Glasgow, Scotland, 10-13 July.

(1995) "Selling and Processing Law: Legal Work at Franchise Law Firms," Law \& Society Review 29:703-29.

\section{CASES CITED}

Bates v State Bar of Arizona, 433 US 350 (1977).

Florida Bar v West-For-It, Inc., 515 US 618 (1995).

Shapiro v Kentucky Bar Association, 486 US 466 (1988).

\section{Appendix: Study Design and Data Sources}

The primary source upon which the analysis reported in this paper was based (the Wisconsin Contingency Fee Study) involved a variety of types of data collection:

- a structured survey of contingency fee practitioners to obtain basic descriptive information about the lawyers' practices and information on a sample of cases handled by the lawyers;

- observation of lawyers at work to obtain an in-depth understanding of key processes such as case-screening; and

- semi-structured interviewing to ascertain the generalizability of the observations;

In addition, we drew upon two supplemental surveys:

- a survey of recipients of direct mail from attorneys carried out on behalf of the Wisconsin Board of Attorneys Professional Responsibility (BAPR); and

- questions included on the statewide Wisconsin Opinions survey of public opinion. 


\section{A. PRACTITIONER SURVEY}

The survey of contingency fee practitioners, which was carried out during the fall of 1995, relied upon a sampling frame defined by the Litigation Section of the State Bar of Wisconsin. ${ }^{40}$ Lawyers provided a total of 511 usable responses representing an estimated response rate of 47.7 percent. ${ }^{41}$ To obtain information on a sample of actual cases, the survey requested data on up to three cases: The case that closed most recently after a trial had at least begun, the case that closed most recently after filing but before the start of trial, and the case that closed most recently before filing. The "most recent" strategy provides an approximation to random sampling, and asking about the three different disposition stages provides for stratification along the key dimension of when a case is closed. ${ }^{42}$ Overall, lawyers provided information on 989 cases ( 332 unfiled, 390 filed but not tried, and 267 that went to trial). The survey was executed by the University of Wisconsin Survey Center.

\section{B. OBSERVATION IN LAWYERS' OFFICES}

This article's senior author's observations in law offices, during the winter and early spring of 1996, involved three different practices. Only one lawyer who was approached refused to participate. ${ }^{43}$ The three lawyers were extremely cooperative. The observer was excluded from very little that was relevant to the research (e.g., a firm "business meeting" in one practice, a trip to talk to an expert in another, and a number of noncontingency-feerelated events in the third). The three settings were very different. One was a specialist plaintiffs' firm; one was a contingency fee plaintiffs' specialist in a medium-sized, general-practice firm, and one was the "litigation" (broadly defined to include criminal and family as well as civil work) specialist in a small, general-practice firm.

\section{SEMI-STRUCTURED INTERVIEWS}

A total of forty-seven semi-structured interviews were carried out, twentyeight with contingency fee practitioners, thirteen with litigation defense lawyers, and six with current or retired insurance claims adjusters; the interviews were conducted between May and October, 1996. The sample of contingency fee practitioners was drawn using a combination of legal directories and Yellow Page advertisements; these interviews averaged about one hour in length, and all were tape recorded and transcribed. The defense-side respondents were identified from directories and in the course of interviews with other respondents. ${ }^{44}$ These interviews were conducted by telephone and, with one exception, were tape recorded and transcribed. 


\section{SURVEY OF DIRECT MAIL RECIPIENTS}

In 1996, as part of its consideration of whether or not to impose a thirty-day rule (i.e., ban such mailings for thirty days following the injury), the Wisconsin Board of Attorneys Professional Responsibility (BAPR) commissioned a survey of recipients of direct mail. The survey was conducted by the University of Wisconsin Survey Center (UWSC). Using lists of names filed with BAPR by lawyers using direct mail, UWSC's interviewers completed telephone interviews with 503 persons whom BAPR's records indicated had received one or more mailings from attorneys; at least twenty-one different law firms were involved (Sweet 1997:2-3). The survey was carried out in the fall of 1996. We have available both the report prepared by UWSC (Sweet 1997) and the original data that were collected.

\section{E. WISCONSIN OPINIONS SURVEY}

The Wisconsin Opinions survey is a statewide, omnibus public-opinion survey carried out quarterly by the Wisconsin Survey Research Laboratory. It is a statewide telephone-interview survey employing a sample drawn using standard random digit dial (RDD) sampling techniques. We included several questions on the spring 1997 edition of that survey. The survey provided data from 409 respondents for analysis. 
